\title{
Anticancer Potential of Raddeanin A, a Natural Triterpenoid Isolated from Anemone raddeana Regel
}

\author{
Irum Naz ${ }^{1}$, Shanaya Ramchandani ${ }^{2}$, Muhammad Rashid Khan ${ }^{3, *}$, Min Hee Yang ${ }^{4}$ \\ and Kwang Seok Ahn ${ }^{4, *(D)}$ \\ 1 Department of Biochemistry, Faculty of Biological Sciences, Quaid-i-Azam University, \\ Islamabad 45320, Pakistan; irumnaz@ps.qau.edu.pk \\ 2 The University of Melbourne, Parkville, VIC 3010, Australia; ramchandanishanaya@gmail.com \\ 3 Higher Education Commission of Pakistan, Islamabad 44000, Pakistan \\ 4 KHU-KIST Department of Converging Science and Technology, Kyung Hee University, Seoul 02447, Korea; \\ didmini@naver.com \\ * Correspondence: mrkhanqau@yahoo.com (M.R.K.); ksahn@khu.ac.kr (K.S.A.); \\ Tel.: +92-333-5091684 (M.R.K.); +82-2-961-2316 (K.S.A.)
}

Academic Editors: Maria Emilia de Sousa and Honorida Cidade

Received: 31 January 2020; Accepted: 21 February 2020; Published: 25 February 2020

\begin{abstract}
Natural compounds extracted from plants have gained immense importance in the fight against cancer cells due to their lesser toxicity and potential therapeutic effects. Raddeanin A (RA), an oleanane type triterpenoid is a major compound isolated from Anemone raddeana Regel. As an anticancer agent, RA induces apoptosis, cell cycle arrest, inhibits invasion, migration and angiogenesis in malignant cell lines as well as in preclinical models. In this systemic review, the pharmacological effects of RA and its underlying molecular mechanisms were carefully analyzed and potential molecular targets have been highlighted. The apoptotic potential of RA can be mediated through the modulation of Bcl-2, Bax, caspase-3, caspase-8, caspase-9, cytochrome c and poly-ADP ribose polymerase (PARP) cleavage. PI3K/Akt signaling pathway serves as the major molecular target affected by RA. Furthermore, RA can block cell proliferation through inhibition of canonical $\mathrm{Wnt} / \beta$-catenin signaling pathway in colorectal cancer cells. RA can also alter the activation of NF- $\mathrm{kB}$ and STAT3 signaling pathways to suppress invasion and metastasis. RA has also exhibited promising anticancer potential against drug resistant cancer cells and can enhance the anticancer effects of several chemotherapeutic agents. Overall, RA may function as a promising compound in combating cancer, although further in-depth study is required under clinical settings to validate its efficacy in cancer patients.
\end{abstract}

Keywords: raddeanin A; malignant; PI3K/AKT; signaling pathways

\section{Introduction}

Cancer is a disease which arises through uncontrolled cell division leading to the formation of a tumor, which metastasizes to other body parts through the lymphatic and circulatory systems [1]. According to latest reports, around 18.1 million people were affected worldwide from different types of cancer in 2018. Up to 9.1 million cancer deaths were reported in 2018 and an increase up to 20.3 million is expected in 2026 [2]. Asia had the highest cancer death rate (57.3\%), followed by Europe and America at $20.3 \%$ and $14.4 \%$, respectively. Most of the deaths were attributed to lung cancer (2.1 million) followed by breast cancer (2.1 million) and colorectal cancer (1.8 million) [3]. The mortality rate of cancer can be reduced by understanding the etiology of cancer through advancement of diagnosis techniques, prevention strategies and treatment [4]. Cancer therapies including surgery, radiotherapy, chemotherapy and molecular targeted therapy have stabilized cancer prevalence to some extent [5], 
but unfortunately, these therapeutic strategies have been found to be less effective due to late diagnosis, lack of selective therapeutics, high toxicity, and ability of cancer cells to develop resistance against available treatments [6]. Therefore, several attempts have been made to develop novel treatments in fighting cancer and to improve patient survival.

Along with various available treatments, the use of natural plant products as medicines provides a new horizon for the treatment of various types of diseases [7-11]. The source of about $60 \%$ of the available drugs are natural raw materials from plants [12-17]. Natural drugs being used in clinics such as paclitaxel, vinblastine and camptothecin have gained a considerable amount of importance due to their reduced side effects [18]. Saponins, particularly triterpenoid saponins, have been used in Traditional Chinese Medicine (TCM) to cure cancer malignancies, for instance, they target the metastatic, invasive and angiogenic potential of cancer cells [19-21]. Saponins are also reported to reduce the resistance of neoplastic cells against chemotherapeutic agents, which is one of the protective mechanisms of cancer cells [22,23]. The progression of cancer cells is primarily mediated through the activation of multiple signaling pathways including the deregulation of MAPK, JAK/STAT and PI3K/Akt pathways which support carcinogenesis [24-27].

Anemone raddeana Regel is a medicinal plant, recognized by its vernacular name as "Liangtoujian" in China. The distribution of this plant is not only limited to China, but throughout the globe, particularly in Russia, Korea, and Japan [28,29]. The rhizome of Anemone raddeana Regel is used in Chinese conventional therapies to cure rheumatism, arthritis, neuralgia, paralysis and other diseases [30-32]. The anemone herb contains oleanane triterpenoid saponins accompanied by lactones, alkaloids, saccharide, triterpenoids and fats [33,34]. In the past few years, various bioactive saponins compounds have been extracted from this plant, including RA, which has gained importance due to its anti-inflammatory, analgesic, and antitumor activities [33].

RA (C47H76O10) is an oleanane class triterpenoid saponin, isolated from the roots of Anemone raddeana, possessing a 3-O- $\alpha$-L-rhamnopyranosyl-( $1 \rightarrow 2)-\beta$-D-glucopyranosyl- $(1 \rightarrow 2)-\alpha-\mathrm{L}-$ arabinopyranoside as the sugar moiety (Figure 1) [31]. The anticancer potential of RA is linked with the presence of sugar moieties and its carboxyl group (-COOH) at the C-28 position (Figure 1). The free carboxyl group plays an important role in the cytotoxic potential of RA. In addition, the presence of rhamnopyranose, glucopyranose and arabinopyranosyl groups can also act as important moieties to enhance its therapeutic potential.

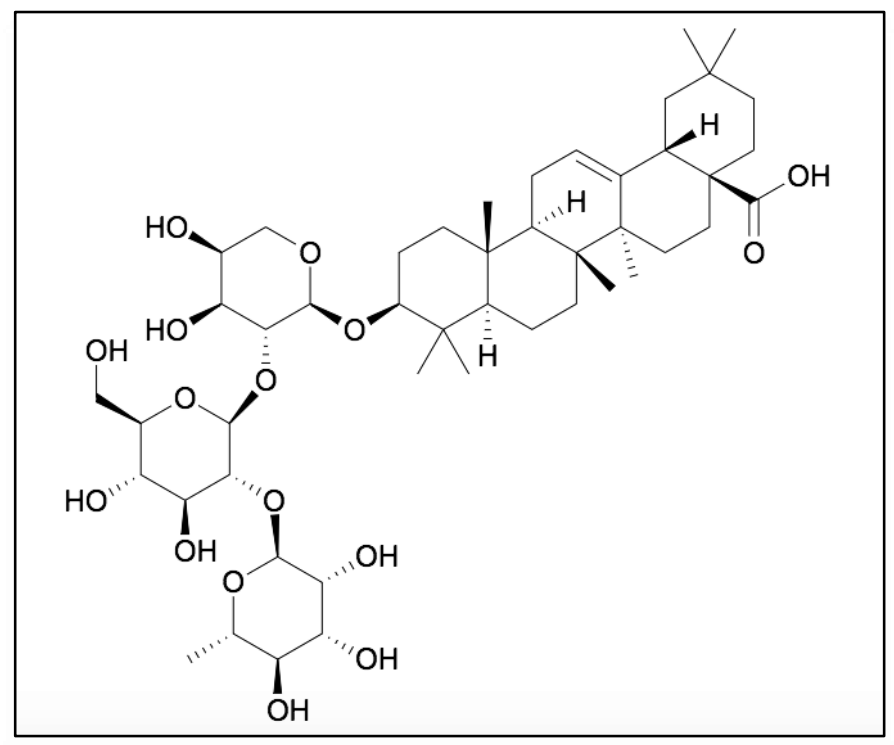

Figure 1. Molecular structure of RA. 
A study reported that the modification at C-28 through esterification can lead to the reduction of cytotoxic potential, thus further confirming the role of this carbon moiety in the biological activities reported for RA [31]. Various studies has shown that RA possesses cytotoxic potential through inhibition of proliferation, invasion and induction of apoptosis in multiple human carcinogenic cells including breast cancer, hepatocellular carcinoma, gastric cancer, and non-small cell lung carcinoma cells [35-38]. In addition, RA has also shown inhibitory properties at low concentrations against histone deacetylases (HDACs), further suggesting its cytotoxicity against cancer cells [31]. Likewise, on account of its reported pharmacological safety, RA can be used in combination with other anti-cancer drugs to enhance the sensitivity against resistant tumor cells. In this review article, the cytotoxic and therapeutic potential of RA has been comprehensively analyzed.

\section{Molecular Targets of RA}

Tumorigenic cells can lead to the deregulation of multiple signaling pathways. Hence, compounds that act on multiple targets are required in the deterrence and treatment of cancer malignancies [39-42]. Various studies show the consecutive activation of major signaling pathways which leads to activation of downstream proteins, and contributes to survival, angiogenesis, and metastasis of cancer cells (illustrated in Figure 2). These include the PI3K/Akt pathway, signal transducer and activator of transcription 3 (STAT3) pathway, and nuclear-factor kappa B (NF-kB) pathway [43-54].

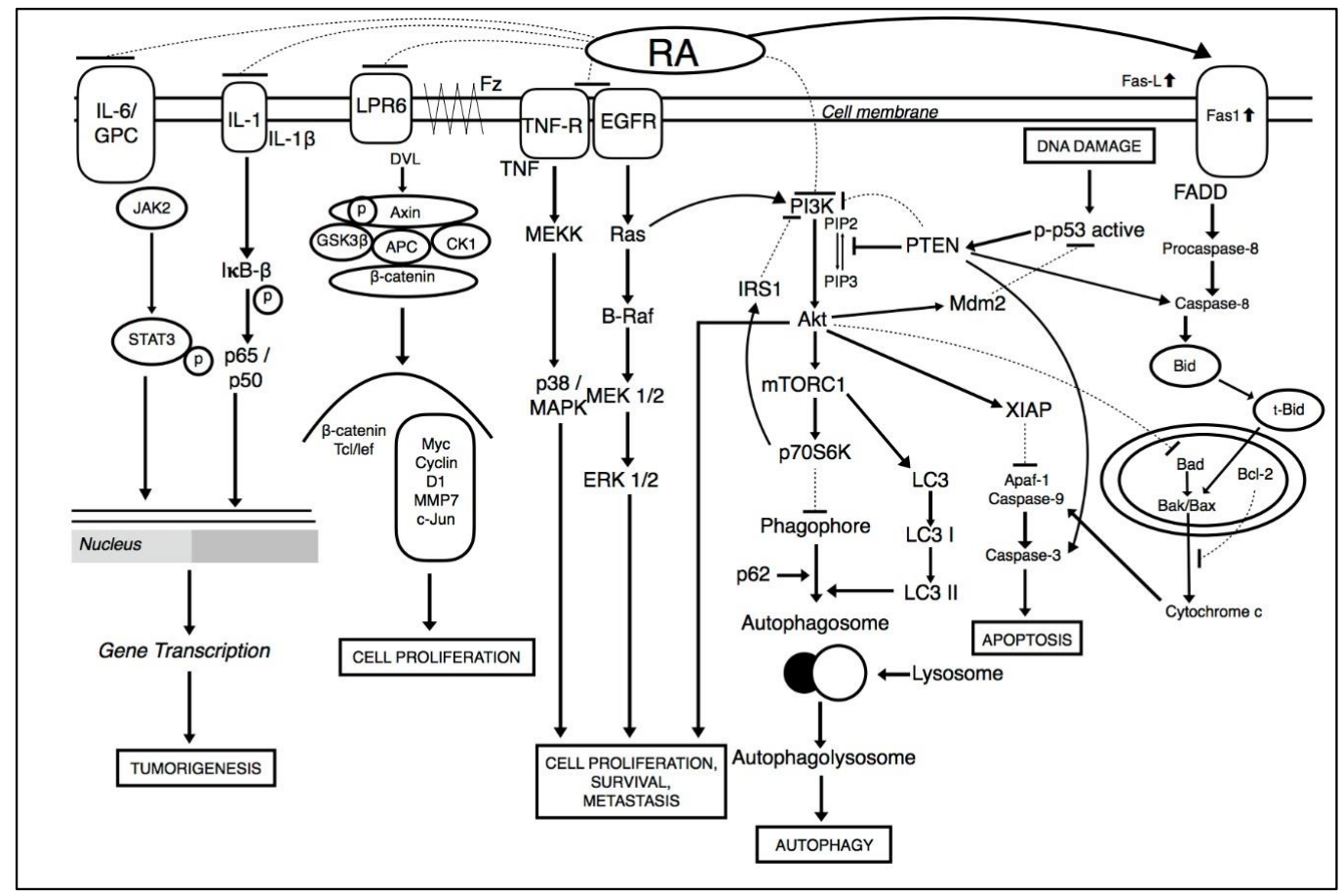

Figure 2. Multiple molecular pathways affected by RA.

Among these pathways, PI3K/Akt pathway is a major signaling pathway that is constitutively turned on and can activate a number of downstream proteins during carcinogenesis. PI3K/Akt is a serine-threonine kinase which is regulated by phosphoinositide dependent kinase-1 (PDK1) when it gets bound with phosphatidylinositol trisphosphate $\left(\mathrm{PIP}_{3}\right)$ on the surface of cell membrane $[44,55-61]$. PDK1 phosphorylates AKT to p-AKT which indirectly activates mTOR pathway [44,55-57]. Together, $\mathrm{PI} 3 \mathrm{~K} / \mathrm{AKT} / \mathrm{mTOR}$ signaling pathway can regulate cellular proliferation, metabolism, survival, and angiogenesis [62-66]. RA treatment reduced cancer cell proliferation by modulating the PI3K/Akt signaling pathway [67]. RA was found to reduced angiogenesis and autophagy by abrogating Akt/PI3K mediated activation of mTOR pathway in breast cancer cells. Together, PI3K/Akt/mTOR lead to the 
activation of EeF-2K which is a key regulator of autophagy [66-68]. In addition, RA also induces apoptosis in multiple cancer through the downregulation of mitochondrial dependent pathways. As potent inducer, it inhibits pro-survival of B-cell lymphoma 2 family members (Bcl-2) and induces the activation of Bax (Bcl-2 associated X protein), cytochrome c, activated caspase-3, caspase-8, caspase- 9 and poly-ADP ribose polymerase (PARP) cleavage. RA also downregulated cell proliferation through the inhibition of cyclins and cyclin dependent kinase complexes such as cyclin E/CDK2 and cyclin D1/CDK4 [69]. Moreover, RA effectively inhibited NF-KB ligand (RANKL) which mediated the upregulation of downstream signaling pathways such as NF-KB, MAPK, and SRC/AKT, to affect osteoclast differentiation, which results in bone resorption in breast cancer [69-72].

RA treatment effectively inhibited the initiation and proliferation of colorectal cancer cells through the suppression of the canonical Wnt/ $\beta$-catenin signaling pathway. The inhibition was conducted by inactivating the Wnt co-receptor LRP6 and phosphorylating GSK-3 $\beta$, an activator of downstream target genes c-Myc and Cyclin D1 [45,73,74]. c-Myc activation links with the activation of pleiotropic transcription factor, cell cycle progression, proliferation, and metabolism. Furthermore, treatment with RA suppressed invasion and osteosarcomas through the modulation of NF- $\mathrm{KB}$ signaling pathways by targeting $I \kappa B \alpha$ phosphorylation to attenuate transcriptional activity of the NF- $\kappa B$ signaling pathway. These mechanisms lead to the downregulation of downstream matrix metallopeptidase-2 (MMP-2) and matrix metallopeptidase-9 (MMP-9) proteins [37,52]. These proteins are associated with the invasive and migratory potential of cancer cells [37]. Another finding reveals that RA initiated apoptosis and inhibited metastasis in osteosarcoma cells by stimulating ROS levels to trigger JNK activation. RA also suppressed MAPK and ERK pathways involved in resistance of cell growth, metabolism, autophagy [75], induction of apoptosis [76,77], and invasion [37]. In addition, RA has been reported to modulate STAT3 transcription factors involved in the expression of a large number of genes which plays a role in many physiological processes such as development, differentiation, metabolism, immunity and cancer progression in osteosarcoma [78]. RA was found as a potential antiangiogenic candidate through the modulation of VEGF mediated phosphorylation of VEGFR2 and downstream protein kinases FAK, PLC $\gamma 1$, JAK2, Src and Akt in colorectal cancer tumors [79].

\section{Pharmacokinetics Studies}

Due to the rapid dispersion and removal, RA exhibits a low bioavailability and concentration in rat plasma. This may be due to the high molecular mass (897.1 D) of RA and poor membrane permeability as a result of the hydrophilic sugars in the RA structure. Moreover, this compound suffers from a short half-life and less systematic exposure due to the vulnerability of fast and large scale biliary excretion through active transport, as RA belongs to the saponins family [80]. A simple, fast and sensitive high-performance liquid chromatography electro spray ionization tandem mass spectrometry (LC-ESI-MS/MS) method was employed to characterize the presence of RA in rat plasma. In vivo studies were conducted using an RA concentration of $2 \mathrm{mg} / \mathrm{kg}$ administered orally and intravenously to S.D rats. With $2.04-6.52 \%$ precision, $70 \%$ of RA was recovered without any clear matrix effect. The analysis indicated that due to poor lipid solubility, RA depicted less systemic absorption and thereby less bioavailability of $0.295 \%$ in plasma samples. This is identical to nearly all saponins reported previously in literature [81].

Another study was conducted using $0.75 \mathrm{mg} / \mathrm{kg}$ intravenous and intraperitoneal administrations of RA in Sprague Dawley (S.D.) rats. The blood sample was investigated at different time intervals which extended over $24 \mathrm{~h}$ for RA and glycyrrhetinic acid (internal standard) and analyzed under negative electrospray ionization in multiple reaction monitoring (MRM) mode [28]. The study indicated that the absolute recovery of RA was greater than $90.3 \%$ with a retention time of $2.1 \mathrm{~min}$. The apparent distribution volume of RA was $0.11 \mathrm{~L} / \mathrm{kg}$ less than total body volume $0.67 \mathrm{~L} / \mathrm{kg}$ reflecting that RA widely disperses in blood compartments as compared to extravascular tissues. A recent in vivo study was carried out on mice by an LC-MS/MS system [82]. All mice were fed a single oral dose of 1.5 $\mathrm{mg} / \mathrm{kg}$ and a blood sample was taken at different time intervals. The plasma of samples was stored at 
$-80{ }^{\circ} \mathrm{C}$ for analysis. The study reveals that maximum concentration of RA was absorbed quickly at time duration of $0.33 \mathrm{~h}$. They found low bioavailability with highest concentration of $12.3 \mu \mathrm{g} / \mathrm{L}$. This dose of RA was the same as found in previous studies. Furthermore, RA exhibited rapid removal with a half-life of $3.5 \mathrm{~h}$ and it couldn't be detected in the plasma after $6 \mathrm{~h}$. The pharmacokinetic study of RA and its tissue distribution was observed in mice. After oral administration, among gastro-intestinal organs, the highest concentration of RA was detected in the stomach, followed by the colon and caecum. However, after $4 \mathrm{~h}$ of oral administration, RA could not be detected in any gastrointestinal organ [83]. The rapid dispersion and removal of RA was in accordance with the low bioavailability and low concentrations in rat plasma [28]. These studies depicted the low bioavailability of RA in plasma, although proper routes of administration are yet to be determined.

\section{Role of RA in Cancer Prevention and Treatment}

The therapeutic potential of RA against various cancers, including prostate, breast, gastric, colon, hepatic, cholangiocarcinoma, osteosarcoma, and glioblastoma has been extensively reported. Studies indicated that RA triggers apoptosis, inhibits proliferation, angiogenesis, and proved to be anti-metastatic in different cancers (Table 1). Hence, the mechanism of action of RA against different malignancies are described below.

\subsection{Breast Cancer}

Breast cancer is a clinically complicated condition with a high incidence and mortality rate in developed countries [84-88]. According to the vicious cycle of bone metastasis, bone cells can interact with breast cancer cells in which tumor cells release pro-osteoclastic factors to induce osteoclastogenesis, while the bone matrix releases pro-tumorigenic growth factors. This in turn can augment tumor expansion [89,90]. To impose osteoclast differentiation and consequently bone resorption, breast cancer cells release inflammatory cytokines such as nuclear factor- $\kappa B$ (NF- $\kappa B$ ) ligand (RANKL), which leads to the activation of downstream signaling pathways such as MAPK, NF- KB, and SRC/AKT [70-72]. The studies of the therapeutic effect of RA specifically showed the inhibition of SRC/AKT pathway. In vitro, RA effectively prevented the RANKL associated osteoclastogenesis on bone marrow-derived macrophages (BMMs) and osteoblast differentiation [36]. Consistent with this result, treatment of RA at different concentrations considerably inhibited the Ti-particle-induced osteolysis by downregulating SRC/AKT signaling pathway in in vivo mice calvarial model. Hence, RA inhibited RANKL regulated SRC expression, and ultimately downregulated the AKT pathway which leads to the inhibition of osteoclastogenesis [36]. To get insight into the RA mechanism and the pathway, researchers found that RA treatment can cause inhibition of AKT phosphorylation, which was later rescued by using AKT activator SC-79. Hence these findings proved that RA specifically directed PI3K/Akt pathway, without interfering with MAPK and NF-KB signaling pathways. In vivo, Ra has been reported to restore osteolysis and decreased trabecular separation in the osteolysis female mouse model.

Another article reported by Guan et al., indicated that RA treatment induces cellular apoptosis and inhibits invasion and angiogenesis through the modulation of P13K/AKT/mTOR signaling pathway $[64,65]$. Importantly, this inhibition specifically reduced the multidrug resistance, which rendered various antitumor therapies as ineffective in breast cancer. Moreover, application of RA on breast cancer cell lines (MDA-MB-231, MCF-7 and T47D) induced autophagy and cytotoxicity through modulation of Akt-mTOR-eEF-2K signaling pathway, as evidenced by an elevated level of autophagy marker LC3, which is also considered as one of the hallmarks of cancer [67]. Upon pre-treatment with chloroquine at $20 \mu \mathrm{mol} / \mathrm{L}$ (an autophagy inhibitor), RA considerably enhanced cytotoxicity and induced apoptosis via intrinsic pathways through downregulating anti-apoptotic proteins (Bcl-2, Bcl-xL and Mcl-1) and upregulating caspase-3 and PARP expression. The morphological changes induced by apoptosis were also noticed by nuclear shrinkage, chromatin condensation, and fragmentation. Hence, it is suggested that through the modulation of AKT and autophagy, RA can reinforce the substantial level of apoptosis in breast cancer cells. 


\subsection{Cholangiocarcinoma}

Cholangiocarcinoma (CCA) is a rare biliary adenocarcinoma characterized by aggressive metastatic and invasive tumors with poor outcomes [91,92]. Due to late diagnosis and vigorous growth, effective treatment is not available against CCA yet. To date, surgical resection remains the only therapeutic approach, but most cases result in death due to late diagnosis [93]. In addition, the resistance of cancerous cells towards available chemotherapeutics is one of the leading challenges [94]. 5-Fluorouracil (5-FU) is currently used in clinics as a chemotherapeutic agent, but due to resistance against CCA cells, the efficacy of this compound has been remarkably reduced Antitumor effect of 5-FU is enhanced by rosemary extract in both drug sensitive and resistant colon cancer cells [94]. The administration of RA promoted apoptosis in four cholangiocarcinoma cell lines. Amidst all, RA specifically impaired migration and hindered colony formation in LIPF155C and RBE cell lines. RA through its antitumor effect, sensitized bile duct cancer cells toward 5-FU and further mediated apoptosis in a 5-FU-resistant cell line. The Wee1 belongs to a protein kinase family involved in cell proliferation by halting cell cycle arrest in tumor cells $[95,96]$. RA increased apoptosis and impaired cellular functions via the activation of the Wee1 dependent signaling mechanism in RBE cell lines. The combined treatment of RA along with 5-FU $(35 \mu \mathrm{M})$ synergistically downregulated the expression of Bcl-2, cyclooxygenase-2, and Wee1 and upregulated Bax. In addition, RA mediated cell cycle arrest by modulating cell cycle-related protein cyclin E/D1. Through this process, the cyclin family forms an orchestrated series of molecular complexes to regulate cell cycle progression. In response to DNA damage, cyclin D-Cdk4/6 and cyclin E-Cdk2 in particular regulates G1-S transition [95,97]. Therefore, a high level of E/D1 cyclin protein can act as pro-apoptotic factors, possibly involved in the sensitization of cancerous cells toward radiation [98]. Hence, the synergistic effect of RA and 5-FU could be a potential therapeutic approach for cholangiocarcinoma.

\subsection{Colorectal Cancer}

Colorectal cancer (CRC) is a highly prevalent cancer globally and the third-leading cause of death after lung and breast cancer $[99,100]$. Cancer cells have the ability to induce angiogenesis, invasion, and metastasis to invade other parts of the body [101]. Ying and co-workers highlighted in their research that RA inhibited the progression of angiogenesis and metastasis of colorectal tumor [79]. RA successfully inhibited HUVEC proliferation and orchestrated the process of angiogenesis, including endothelial cell proliferation, motility, and capillary-like tube formation without affecting HCT-15 healthy endothelial cells, specifying its activity only against tumor endothelial cell. In the chick embryo chorioallantoic membrane (CAM) model, RA treatment effectively blocked blood vessel formation in a dose-dependent manner. The study was further extended to zebrafish model, where RA treatment was shown to disrupt nearly $68 \%$ of intersegmental vessel (ISVs) formation along with the deformed morphology of zebrafish. In HCT-15 xenograft mice models, RA dose-dependently showed substantial antiangiogenic potential through a remarkable decrease in micro vessel density (MVD) along with reduced tumor growth and weight. The above mentioned antiangiogenic effect of RA was mediated through the phosphorylation of VEGF-induced vascular endothelial growth factor 2 and the inhibition of downstream kinases and signaling pathways including focal adhesion kinase (FAK), JAK2, PLC $\gamma 1$, Src, and Akt inhibition, involved in survival, migration and proliferation of EC. This mechanism was further hypothesized by molecular docking simulation, based on which RA pentacyclic triterpene moiety docked at the ATP-binding pocket of VEGFR2 kinase domain occupied with six amino acids and facilitate the formation of VEGFR2-RA complex to inhibit downstream molecular pathways.

PI3K/Akt signaling pathway constitutively expressed in malignant cells and activate several downstream proteins to regulate cell proliferation, cell metabolism, cell survival, and angiogenesis [62-65]. Activated PI3K/Akt pathway indirectly activates mTOR pathway which subsequently triggers activation of genes involved in apoptosis and cell cycle progression [8]. Chunqin et al. discovered that RA treatment dose-dependently stimulated apoptosis, G0/G1 cell cycle arrest and blocked cell cycle proliferation in colorectal HCT-116 cell line possibly through inhibiting the PI3K/AKT signaling pathway [102]. In the 
HCT116-xenograft mouse model, RA significantly reduced the tumor growth, whereas apoptotic cells were also seen in tumor tissue [102]. RA treatment significantly decreased the protein level of cyclin D1, cyclin E, p-PI3K, and p-AKT, suggested the strong anti-tumor potential of RA in vivo HCT116 cells induced xenograft mice.

$\mathrm{Yu}$ and co-workers discovered the anti-proliferative and apoptotic effects of RA in colorectal LOVO and SW480 cell lines [103]. The study was further extended to in vivo xenograft mouse model, where RA had significantly inhibited the tumor growth through modulation of Wnt/ $\beta$-catenin signaling via downregulation of p-LRP6, upregulation of AKT inactivation, inhibition of $\beta$-catenin and removal of GSK-3 $\beta$ inhibition. In addition, RA prevented tumor through modulation of NF- $\mathrm{B}$ signaling pathway, inhibited phosphorylation of IкB- $\alpha$ which led to an induction of the mitochondrial apoptotic pathway.

\subsection{Glioblastoma}

Glioblastoma multiforme (GBM) is an incurable primary brain tumor with a low long-term survival rate in affected patients. According to a recent report, the estimated incidence rate of GBM is around 5.62 per 100,000 people and the rate is growing [104,105]. Despite standard treatment, the aberrant metastatic potential of brain tumor cells, and incomplete surgical resection has declined the survival rate of less than one year after diagnosis [106]. Peng and coworkers have suggested the therapeutic potential of RA in reducing cell viability of four GBM cell lines (G112, T98, U87, and U251) compared with control cells [107]. RA treatment in these cell lines effectively reduced the level of MMP-2 and MMP-9, linked to the invasive and migratory potential of cancer cells. Treatment with RA induced apoptosis in glioma cells through increased ROS production, which lead to the activation of Jun N-terminal kinase (JNK) signaling pathway, which mediated high Bax/Bcl-2 ratio and subsequently caspase-3 and PARP upregulation. The activation of ROS/JNK signaling pathway was further verified by targeting cells with antioxidant NAC (N-Acetyl-L-cysteine) and caspase inhibitor (z-VAD-fmk), as a result reduced apoptotic rate, p-JNK and caspase-3 level authenticated the activation of this pathway in colorectal cells (T98 and U251). Interestingly, appearance of apoptotic cells after z-VAD-fmk treatment highlighted the occurrence of other possible mechanism in inducing apoptosis. Therefore, RA induced cell death also triggered through another mechanism along with apoptotic pathway. Furthermore, treatment of RA induced autophagy in glioma cells, since it is known to either support or inhibit apoptotic signaling. However, in this study, the application of autophagy inhibitors class III PI3K and 3-MA, exacerbated the RA mediated apoptosis in U251 glioma cell as noticed with caspase-3 overexpression. In U251-harbouring xenografts nude mice model, RA treatment exhibited curative effect with a significant drop in tumor size and induced apoptosis as noted by elevated level of caspase-3, LC3-I to LC3-II conversion and p-JNK.

\subsection{Gastric Cancer}

Gastric cancer (GC) is the third most extensively frequent cancer in males due to the increased resistance of gastric cancer cells toward clinically used chemotherapeutic agents $[3,105,108]$. The gastric cancer patient typically suffers relapse after surgery, which reduces the survival rate to less than five years [109-114]. Gang et al. discovered that RA treatment activated apoptosis and invasion in three dissimilar differentiation stage gastric cancer (GC) cells (BGC-823, MKN-28, and SGC-7901) [115]. Amongst all, RA remarkably reduced proliferation, adhesion, invasion, and migration in BGC-823 cells. However, a study reported by Hao et al., [37] also suggested the anti-proliferative potential of RA against SGC-7901 cells in a concentration dependent manner. Administration of RA on these cells hinder proliferation and induced apoptosis via mitochondrial apoptotic signaling cascade led to a drop in Bcl-2, Bcl-xL, survivin expression, whereas simultaneously upregulated the pro-apoptotic Bax, caspase-3, caspase-8, caspase-9 expression in addition to activation of PARP cleavage. Besides, the RA also attenuated the invasive, migratory, and angiogenic potential of tumor cells by inhibiting MMP-2, MMP-9, MMP-14, and Roc proteins. On the contrary, the E-cadherin (E-cad) expression and reversion inducing cysteine-rich protein with Kazal motifs (RECK) was significantly upregulated, 
which negatively associated with MMPs, therefore supported the notion that RA specifically prevented angiogenesis via MMPs inhibition. Furthermore, treatment of RA induced apoptosis and autophagy through modulation of p38/MAPK pathway as indicated by high level of p-p38 and ERK level in GC cells $[75,76]$. Moreover, LC3I to LC3II conversion along with phosphorylation of p-mTOR notably depicted the existence of autophagy in these cells, which probably protect cancerous cells from apoptosis and reduce the inhibitory potential of target compound [115]. Therefore, employing an autophagy inhibitor could be the best choice in RA-mediated apoptosis against gastric cancer cells.

\subsection{Hepatocellular Carcinoma (HCC)}

Hepatocellular carcinoma (HCC) is the aggressive malignancy of the liver and the second leading cause of mortality in the world [3]. Cisplatin is a well-established alkylating compound used regularly in human hepatocellular carcinoma (HCC) chemotherapies and radiotherapy [116], though accompanied by remarkable cytotoxicity $[117,118]$. Clinically, it is used in combination with other drugs to reduce toxicity. Cisplatin performs its function by repressing the tumor cellular DNA repair process [119]. RA, coupled with cisplatin, reduced its toxicity and showed a remarkable synergistic effect against tumor on QGY-7703 cells based on combination index (CI) values less than 0.8. Anaerobic condition in the tumor microenvironment enhanced tumor cell growth and metastasis due to which intracellular ROS production is used to evaluate the underlying proliferation or metastasis of HCCs [120]. RA, in combination with cisplatin, increases the ROS level and also facilitates the oxygen metabolism in HCC cells, including HepG2 and SMMC-7721. In addition, RA enhanced cisplatin effect through increasing sensitivity of resistant cells, which further activated their apoptosis. RA significantly inhibited proliferation by inducing $S$ phase cell cycle arrest, whereas cisplatin induced cell cycle arrest at the G0/G1 stage [121]. The mRNA expression level of apoptotic genes was upregulated for p53 and Bax, whereas simultaneously led to a reduction of Bcl-2 and Survivin proteins [38]. Hence, RA treatment together with cisplatin, could serve as a potential therapeutic target in reducing toxicity of cancerous cells toward commercially available chemotherapeutic agent.

\subsection{Lung Cancer}

Lung cancer is the heterogeneous disease of lungs and the leading cause of global cancer mortality [3]. Among all lung cancers, $80 \%$ of cases belong to non-small cell lung cancer (NSCLC) with gradual increasing incidence and mortality rate [122]. Treatment of RA remarkably inhibited cell proliferation and blocked cell cycle progression of NSCLC H460 cells. RA significantly reduced proliferation of H460 in a concentration-dependent manner. RA modulated the Akt mediated G2/M phase arrest, down-regulated Bcl-2 and cleaved PARP expression, leading to reduced H460 cell proliferation apoptosis induction. These findings suggested the strong therapeutic potential of RA in combating cancer cells and increasing the survival of patients affected by NSCLC [35].

\subsection{Osteosarcoma}

Osteosarcoma is a highly aggressive bone tumor, associated with poor survival. Treatment with RA was shown to exhibit an anti-tumor effect via JNK mediated mitochondrial apoptosis pathway and inhibited metastasis on human osteosarcoma cell lines [123]. RA downregulated Bcl-2/Bax ratio, upregulated cleaved caspase-3 and PARP, as crucial components of apoptosis. RA increased cell apoptotic activity by ROS/JNK phosphorylation and downregulation of NF- $\mathrm{B}$ transcriptional activity through a low level of $\mathrm{p}-\mathrm{I} \kappa \mathrm{B} \alpha$ and $\mathrm{p} 65$ [123]. After pre-treatment with RA, inhibition of p65 results in the sensitization of osteosarcoma cells. In addition, RA represses invasion and migration by downregulating MMP-2/9 level mediated with NF- $\kappa$ B pathway [123]. An in vivo study following exposure of RA in ROS xenograft models also confirmed the anti-cancer effects of RA on human osteosarcoma. Zhuoying and coworkers [124] suggested that RA treatment induced apoptosis and abrogated proliferation in osteosarcoma cells through modulation of the JNK/c-Jun and STAT3 signaling pathways. An in vivo study on tibial xenograft tumor model, administration of apoptosis in OS 
cells, which lead to the reduction of tumor size. Furthermore, another study indicated that RA had shown an antitumor effect in both drug-resistant and non-resistant OS cells [78]. Treatment with RA mediated apoptosis, blocked cell proliferation, as well as restricted colony formation by mediating interleukin-6 (IL-6) induced JAK2/STAT3 pathway. By contrast, RA treatment was shown to increase the levels of MDR1 and STAT3 in resistant OS cells, whereas high expression of these protein is related to the chemoresistance. The expression of MDR1 protein in both drug-sensitive and resistant OS cells, along with downregulation of STAT3 by using siRNA, increased the sensitivity of these cells toward doxorubicin treatment. The combine treatment of RA and doxorubicin increased the doxorubicin uptake by cell, result in increasing toxicity, ablated efflux, and reduced MDR1 expression in drug resistant cells by modulating STAT3 phosphorylation. Consistent with these results, RA reduced tumor growth by promoting apoptosis in doxorubicin-resistant OS tibia orthotopic model. Therefore, RA serves as a potential therapeutic for doxorubicin resistance treatment in OS.

\subsection{Prostate Cancer}

In men, prostate cancer is the most common type of malignancy and does not have therapeutic options in the advanced state $[125,126]$. The castration resistance after androgen deprivation therapy is the ultimate cause of death in castration-resistant prostate cancer (CRPC). The upregulation of full-length androgen receptor (AR-FL) and splice variants (AR-Vs, AR-V7, ARv567es, and AR-V9) are most likely involved in poor prognosis and castration resistance. It is, therefore, an urgent need to develop a drug that acts as a reactivation mechanism in combating CRPC. A recent report showed that RA has effectively attenuated the transcription of AR-FL and splice variants AR-Vs. Docetaxel is a first-line chemotherapy drug that has been implicated in CRPC and mediates its effect through stabilizing microtubules; however, AR-V7 is localized in the nucleus and is independent of the microtubule. Therefore, it remains insensitive toward docetaxel inhibition $[127,128]$. In CRPC cells, RA was reported to selectively target both the full-length AR-FL and splice variant AR-V mRNA expression and increase the growth inhibitory efficacy of docetaxel synergistically in both time- and dose dependent manners. RA inhibition is entirely dependent on AR other than androgen, as AR-null cells are left unaffected by RA treatment. This inhibition is of utmost importance because none of the drugs available in the market can directly target the full length and splice variants of the AR. However, compounds other than RA have been shown to decrease the levels of AR-FL and AR-Vs pre-clinically [129-131]. Taken together, the study provided a rationale for RA and its combination treatment against CRPC.

\subsection{Chemosensitizing Properties of RA}

Surgery, radiotherapy and chemotherapy are conventional clinical treatments for cancer [132]. However, more and more tumors have become resistant to chemotherapy in recent years, which has become a major obstacle to cancer treatment [111,113,114,133-135]. 5-FU is the most common chemotherapeutic compound for cancer treatment [69]. RA sensitized cholangiocarcinoma cell lines to 5-FU treatment and ameliorated 5-FU resistance in bile duct cancer cells through activating multiple cell cycle and apoptosis-related factors, such as COX-2, Bax, Bcl-2, and cyclins E/D1 [136]. RA may also have the potential to enhance the growth inhibitory efficacy of docetaxel, the first-line chemotherapy for prostate cancer [137]. The growth and survival of prostate cancer cells rely on androgen receptor (AR) [136]. Splice variants of AR (AR-V) expression have been proposed to be a mechanism of docetaxel resistance. RA enhanced the growth inhibitory efficacy of docetaxel through suppressing both full-length (AR-FL) and AR-V expression and activities. Peng $e$ t al., reported that the activation of STAT3/NFIL3 signaling axis results chemotherapeutic resistance. In addition, RA reversed STAT3/NFIL3 signaling axis-mediated chemotherapy resistance in drug-resistance choriocarcinoma cell lines such as JEG-3/MTX (methotrexate-resistant-JEG-3 cells), JEG-3/5-FU-resistant-JEG-3 cells), and JEG-3/VP16 (etoposide-resistant-JEG-3 cells) [138]. 
Table 1. A list of different cancers affected by RA under in vitro and in vivo settings.

\begin{tabular}{|c|c|c|c|c|c|c|}
\hline Cancer & Model & Experiment & Dosage & Anti-Cancer & Mechanisms of Action & Ref \\
\hline \multirow[t]{3}{*}{ Colorectal cancer } & $\begin{array}{l}\text { SW480, LOVO, Caco-2, } \\
\text { HT-29 }\end{array}$ & In vitro & $0-50 \mathrm{mM}, 0.4 \mu \mathrm{M}$ & $\begin{array}{c}\text { Apoptosis, } \\
\text { Anti-proliferative, } \\
\text { Anti-angiogenic }\end{array}$ & $\begin{array}{c}\downarrow \text { Bax } / \text { Bcl-2, } \downarrow \text { Wnt } / \beta \text {-catenin, } \downarrow \text { AKT, } \\
\downarrow \text { GSK-3 } \beta, \downarrow \text { LRP6-p, } \downarrow \text { c-Myc, } \downarrow \text { cyclin D1, } \\
\downarrow \text { NF-kB, } \uparrow \text { cell cycle arrest }\end{array}$ & [103] \\
\hline & HCT-15 xenograft mice & In vivo & $3 \mu \mathrm{M}$ & $\begin{array}{l}\text { Anti-proliferative, } \\
\text { Anti-invasive, } \\
\text { Anti-migratory, } \\
\text { Anti-angiogenic }\end{array}$ & $\begin{array}{c}\downarrow \text { VEGF, } \downarrow \\
\downarrow \text { VEGFR } 2, \downarrow \text { PLC } \gamma 1, \downarrow \text { JAK }, \downarrow \text { Src }, \downarrow \text { Akt }\end{array}$ & [79] \\
\hline & $\begin{array}{c}\text { HCT116 } \\
\text { HCT116-xenograft mouse }\end{array}$ & $\begin{array}{l}\text { In vitro } \\
\text { In vivo }\end{array}$ & $1-16 \mathrm{mM}$ & $\begin{array}{l}\text { Apoptosis, Reduce tumor } \\
\text { growth }\end{array}$ & $\begin{array}{c}\uparrow \text { caspase-3, } \uparrow \text { PARP, } \uparrow \mathrm{BAX}, \downarrow \mathrm{p}-\mathrm{PI} 3 \mathrm{~K}, \\
\downarrow \mathrm{p}-\mathrm{AKT}, \downarrow \text { cyclin D1, } \downarrow \text { cyclin } \mathrm{E}, \downarrow \mathrm{CDK} 4, \\
\downarrow \mathrm{CDK} 2, \uparrow \mathrm{G} 0 / \mathrm{G} 1 \text { phase arrest }\end{array}$ & [102] \\
\hline Breast cancer & $\begin{array}{c}\text { BMMs, MDA-MB-231 } \\
\text { MCF-7, T47D } \\
\text { BALB/c nu/nu Female mice }\end{array}$ & $\begin{array}{l}\text { In vitro } \\
\text { In vivo }\end{array}$ & $\begin{array}{c}0-0.8 \mathrm{mM}, 2-8 \\
\mu \mathrm{mol} / \mathrm{L} \\
2-10 \mu \mathrm{mol} / \mathrm{L}\end{array}$ & $\begin{array}{c}\text { Apoptosis, } \\
\text { Anti-invasive, } \\
\text { Anti-proliferative, } \\
\text { Reverse Osteolysis }\end{array}$ & $\begin{array}{c}\downarrow \text { MAPK, } \downarrow \text { NF- } \mathrm{KB}, \downarrow \text { SRC/AKT } \\
\downarrow \text { AKT/mTOR signaling } \\
\uparrow \text { Akt-mTOR-eEF-2K }\end{array}$ & [36], [67] \\
\hline Cholangiocarcinoma & $\begin{array}{l}\text { RBE, LIPF155C, LIPF178C, } \\
\text { LICCF }\end{array}$ & In vitro & $\begin{array}{c}0-160 \mu \mathrm{g} / \mathrm{mL}, 13 \\
\mu \mathrm{g} / \mathrm{mL} \\
13 \mu \mathrm{g} / \mathrm{mL}+50 \mu \mathrm{mol} / \mathrm{L} \\
\mathrm{RBE} / 5-\mathrm{FU}\end{array}$ & $\begin{array}{l}\text { Apoptosis, } \\
\text { Anti-migratory, Inhibit } \\
\text { colony formation }\end{array}$ & $\begin{array}{c}\downarrow \text { Cox-2, } \downarrow \text { Bcl-2, } \\
\qquad \text { Wee } 1, \uparrow \text { Bax }, \uparrow c y c l i n \text { D1 } \\
\text { cyclin E }\end{array}$ & [69] \\
\hline Glioblastoma & $\begin{array}{l}\text { G112, T98, U251, U87 } \\
\text { U251-harboring xenografts } \\
\text { in nude mice }\end{array}$ & $\begin{array}{l}\text { In vitro } \\
\text { In vivo }\end{array}$ & $\begin{array}{c}0-8 \mathrm{mM}, 4 \mu \mathrm{M} \mathrm{RA} \\
1 \mathrm{mg} / \mathrm{kg}, 2 \mathrm{mg} / \mathrm{kg} \text { bw }\end{array}$ & $\begin{array}{c}\text { Apoptosis, } \\
\text { Anti-proliferative } \\
\text { Reduce Tumor size, body } \\
\text { weight }\end{array}$ & $\begin{array}{c}\uparrow \mathrm{ROS} / \mathrm{JNK}, \uparrow \mathrm{Bax}, \downarrow \text { Bcl-2, } \uparrow \text { caspase-3, } \\
\uparrow \mathrm{PARP}\end{array}$ & [107] \\
\hline $\begin{array}{l}\text { Hepatocellular } \\
\text { carcinoma }\end{array}$ & QGY-770 & In vitro & $\begin{array}{c}0-55.8 \mu \mathrm{M} \\
29.22 \mathrm{mM} \\
14.71 \mu \mathrm{M} \mathrm{RA}+4.92 \\
\mu \mathrm{M} \\
\text { Cisplatin }\end{array}$ & Reduce ROS & $\begin{array}{c}\uparrow \mathrm{G} 0 / \mathrm{G} 1 \text { phase arrest } \\
\downarrow \mathrm{p} 53, \uparrow \mathrm{Bax}, \downarrow \mathrm{Bcl}-2, \downarrow \text { survivin }\end{array}$ & [38] \\
\hline Prostate cancer & 22Rv1, DU145, PC-3 & In vitro & $\begin{array}{c}0-6 \mu \mathrm{mol} / \mathrm{L} \\
\text { plasma conc. } 4.5 \\
\mu \mathrm{mol} / \mathrm{L}, 3 \mu \mathrm{mol} / \mathrm{L}\end{array}$ & Inhibit growth, & $\downarrow \mathrm{AR}-\mathrm{FL}, \downarrow \mathrm{AR}-\mathrm{V7}$ & [136] \\
\hline
\end{tabular}


Table 1. Cont

\begin{tabular}{|c|c|c|c|c|c|c|}
\hline Cancer & Model & Experiment & Dosage & Anti-Cancer & Mechanisms of Action & Ref \\
\hline Gastric cancer & $\begin{array}{c}\text { SGC-7901 } \\
\text { BGC-823, MKN-28, } \\
\text { SGC-7901 }\end{array}$ & In vitro & $\begin{array}{c}0-16 \mu \mathrm{M}, 8 \mathrm{mM} \\
8 \mu \mathrm{M}, 16 \mathrm{~mL}+50 \\
\mu \mathrm{g} / \mathrm{mL} 5-\mathrm{FU}\end{array}$ & $\begin{array}{c}\text { Apoptosis, Anti-proliferative, } \\
\text { Anti-invasive, } \\
\text { Anti-migratory, Reduce } \\
\text { autophagy }\end{array}$ & 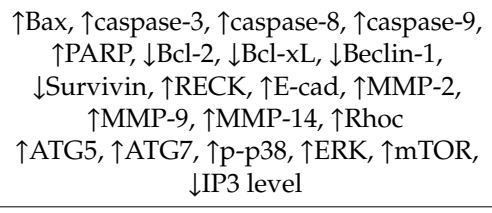 & $\begin{array}{r}\text { [37] } \\
{[115]}\end{array}$ \\
\hline Osteosarcoma & $\begin{array}{c}\text { MG-63, HOS } \\
\text { HOS cell } \\
\text { xenograft mice } \\
\text { tibial xenograft tumor mice } \\
\text { CCK8 orthotopic } \\
\text { Chemoresistant OS mice }\end{array}$ & $\begin{array}{l}\text { In vitro } \\
\text { In vivo }\end{array}$ & $\begin{array}{c}0.2-50 \mu \mathrm{M} \\
1.25,2.5,5 \mathrm{mg} / \mathrm{kg} \\
5 \mathrm{mg} / \mathrm{kg}+1 \mathrm{mg} / \mathrm{kg} \\
\text { Dox }\end{array}$ & $\begin{array}{l}\text { Apoptosis, Anti-invasive, } \\
\text { Anti-metastatic, } \\
\text { Anti-proliferative, inhibit } \\
\text { osteosarcoma, } \\
\text { Reduce tumor growth }\end{array}$ & 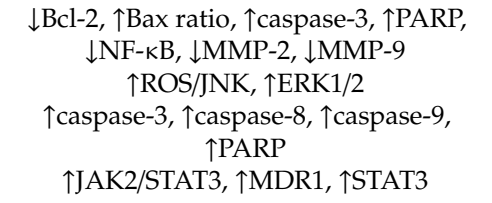 & $\begin{array}{l}{[123]} \\
{[78]} \\
{[124]}\end{array}$ \\
\hline
\end{tabular}




\section{Limitations and Future Prospects}

The diverse pharmacological effects of RA have been analyzed in this review, indicating the therapeutic potential of RA against numerous cancer cell lines. Evidence has suggested that RA shows anticancer potential both in vitro and in vivo animal models. However, in vivo studies are confined to some cancers such as breast, colorectal, prostate and osteosarcoma. In addition, based on previous pharmacokinetic data, low bioavailability of RA in the systemic circulation is a major concern, therefore, there is a need to explore in depth mechanisms in order to increase the compound's bioavailability and to retain the metabolites for an optimal effect. Furthermore, despite having a large number of combination studies with other chemotherapeutic drugs, no clinical study is reported as yet. Hence, in an attempt to get further insights, available data can be employed in clinical settings.

\section{Conclusions}

This review provides a comprehensive detail about the diverse anticancer potential of RA in both in vitro and in vivo studies. The effect of RA is mainly exerted through the induction of apoptosis, cell cycle arrest and the inhibition of cell proliferation along with modulating cell signaling mechanisms in breast, cholangiocarcinoma, colorectal, liver, lung, prostate and osteosarcoma. Amidst various signaling pathways, PI3K/AKT has been the most significantly modulated by RA in different cancers. Furthermore, RA has induced synergistic effects in combination with other chemotherapeutic drug and increases sensitivity of tumor cells to apoptosis without posing toxic effect. Therefore, RA can be used as a novel anticancer agent against those malignancies that have developed resistance to chemotherapy. In preclinical studies, RA significantly reduced tumor growth, tumor size and metastasis. However, the effective concentrations against tumor cells varies depending on the type of cell and in vivo model system. Hence, clinical trials are required to establish the effectiveness of RA in clinical settings. The detailed study concluded that RA can be used as a promising anticancer compound.

Author Contributions: This manuscript is written by I.N. and S.R. It was edited by M.R.K., M.H.Y. and K.S.A. All authors have read and agreed to the published version of the manuscript.

Funding: This work was supported by Higher Education Commission of Pakistan (HEC) grant and National Research Foundation of Korea (NRF) grant funded by the Korean government (MSIP) (NRF-2018R1D1A1B07042969).

Conflicts of Interest: The authors declare no conflict of interest.

\section{Abbreviations}

$\begin{array}{ll}\text { 5-FU } & \text { 5-Fluorouracil } \\ \text { AR-FL } & \text { Androgen Receptor Full Length } \\ \text { ARVS } & \text { Androgen Receptor Splice Variant } \\ \text { BAX } & \text { Bcl2-Associated X Protein } \\ \text { BCL-2 } & \text { B-Cell Lymphoma-2 } \\ \text { BCL-XL } & \text { B-Cell Lymphoma-Extra Large } \\ \text { BMM } & \text { Bone Marrow-Derived Macrophages } \\ \text { CDK1 } & \text { Cyclin Dependent Kinase 1 } \\ \text { CDK2 } & \text { Cyclin Dependent Kinase 2 } \\ \text { CDK4 } & \text { Cyclin Dependent Kinase 4 } \\ \text { CDK6 } & \text { Cyclin Dependent Kinase 6 } \\ \text { CI } & \text { Combination Index } \\ \text { CRC } & \text { Colorectal Cancer } \\ \text { CRPC } & \text { Castration Resistance Prostate Cancer } \\ \text { EGFR } & \text { Epidermal Cell Growth Factor Receptor } \\ \text { EMT } & \text { Epithelial-Mesenchymal Transition }\end{array}$




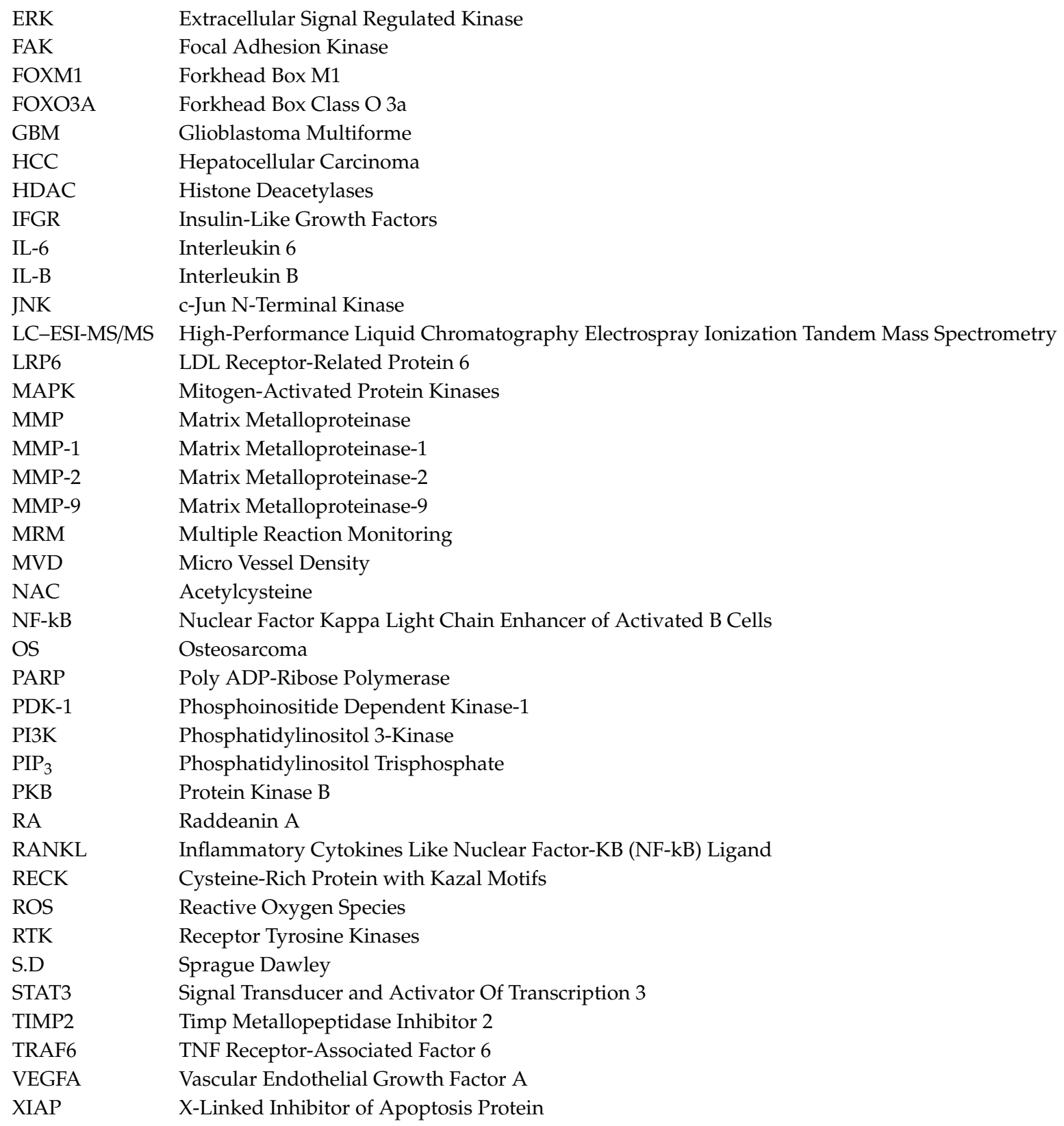

\section{References}

1. Foster, I. Cancer: A cell cycle defect. Radiography 2008, 14, 144-149. [CrossRef]

2. Bray, F.; Ferlay, J.; Soerjomataram, I.; Siegel, R.L.; Torre, L.A.; Jemal, A. Global cancer statistics 2018: GLOBOCAN estimates of incidence and mortality worldwide for 36 cancers in 185 countries. CA Cancer J. Clin. 2018, 68, 394-424. [CrossRef] [PubMed]

3. Torre, L.A.; Bray, F.; Siegel, R.L.; Ferlay, J.; Lortet-Tieulent, J.; Jemal, A. Global cancer statistics, 2012. CA Cancer J. Clin. 2015, 65, 87-108. [CrossRef] [PubMed]

4. Wu, S.; Zhu, W.; Thompson, P.; Hannun, Y.A. Evaluating intrinsic and non-intrinsic cancer risk factors. Nat. Commun. 2018, 9, 3490. [CrossRef] [PubMed]

5. Devita, V.T.; Canellos, G.P. Hematology in 2010: New therapies and standard of care in oncology. Nat. Rev. Clin. Oncol. 2011, 8, 67-68. [CrossRef] [PubMed]

6. Marqus, S.; Pirogova, E.; Piva, T.J. Evaluation of the use of therapeutic peptides for cancer treatment. J. Biomed. Sci. 2017, 24, 21. [CrossRef] 
7. Svejda, B.; Aguiriano-Moser, V.; Sturm, S.; Höger, H.; Ingolic, E.; Siegl, V.; Stuppner, H.; Pfragner, R. Anticancer activity of novel plant extracts from Trailliaedoxa gracilis (W. W. Smith \& Forrest) in human carcinoid KRJ-I cells. Anticancer Res. 2010, 30, 55-64.

8. Deng, S.; Shanmugam, M.K.; Kumar, A.P.; Yap, C.T.; Sethi, G.; Bishayee, A. Targeting autophagy using natural compounds for cancer prevention and therapy. Cancer 2019, 125, 1228-1246. [CrossRef]

9. Kashyap, D.; Tuli, H.S.; Yerer, M.B.; Sharma, A.; Sak, K.; Srivastava, S.; Pandey, A.; Garg, V.K.; Sethi, G.; Bishayee, A. Natural product-based nanoformulations for cancer therapy: Opportunities and challenges. Semin. Cancer Biol. 2019. [CrossRef] [PubMed]

10. Shanmugam, M.K.; Warrier, S.; Kumar, A.P.; Sethi, G.; Arfuso, F. Potential Role of Natural Compounds as Anti-Angiogenic Agents in Cancer. Curr. Vasc. Pharmacol. 2017, 15, 503-519. [CrossRef]

11. Girisa, S.; Shabnam, B.; Monisha, J.; Fan, L.; Halim, C.E.; Arfuso, F.; Ahn, K.S.; Sethi, G.; Kunnumakkara, A.B. Potential of zerumbone as an anti-cancer agent. Molecules 2019, 24, 734. [CrossRef] [PubMed]

12. Demain, A.L.; Vaishnav, P. Natural products for cancer chemotherapy. Microb. Biotechnol. 2011, 4, 687-699. [CrossRef] [PubMed]

13. Hsieh, Y.S.; Yang, S.F.; Sethi, G.; Hu, D.N. Natural bioactives in cancer treatment and prevention. Biomed Res. Int. 2015, 2015, 1. [CrossRef] [PubMed]

14. Yarla, N.S.; Bishayee, A.; Sethi, G.; Reddanna, P.; Kalle, A.M.; Dhananjaya, B.L.; Dowluru, K.S.V.G.K.; Chintala, R.; Duddukuri, G.R. Targeting arachidonic acid pathway by natural products for cancer prevention and therapy. Semin. Cancer Biol. 2016, 40, 48-81. [CrossRef] [PubMed]

15. Dai, X.; Zhang, J.; Arfuso, F.; Chinnathambi, A.; Zayed, M.E.; Alharbi, S.A.; Kumar, A.P.; Ahn, K.S.; Sethi, G. Targeting TNF-related apoptosis-inducing ligand (TRAIL) receptor by natural products as a potential therapeutic approach for cancer therapy. Exp. Biol. Med. 2015, 240, 760-773. [CrossRef] [PubMed]

16. Merarchi, M.; Sethi, G.; Shanmugam, M.K.; Fan, L.; Arfuso, F.; Ahn, K.S. Role of natural products in modulating histone deacetylases in cancer. Molecules 2019, 24, 1047. [CrossRef] [PubMed]

17. Yang, S.F.; Weng, C.J.; Sethi, G.; Hu, D.N. Natural bioactives and phytochemicals serve in cancer treatment and prevention. Evidence-Based Complement. Altern. Med. 2013, 2013, 1. [CrossRef] [PubMed]

18. Chin, Y.-W.; Balunas, M.J.; Chai, H.B.; Kinghorn, A.D. Drug discovery from natural sources. AAPS J. 2006, 8 , E239-E253. [CrossRef]

19. Xia, C.; Chen, L.; Sun, W.; Yan, R.; Xia, M.; Wang, Y.; Yang, D. Total saponins from Paris forrestii (Takht) H. Li. show the anticancer and RNA expression regulating effects on prostate cancer cells. Biomed. Pharmacother. 2020, 121, 109674. [CrossRef]

20. Zhang, T.; Zhong, S.; Li, T.; Zhang, J. Saponins as modulators of nuclear receptors. Crit. Rev. Food Sci. Nutr. 2018, 1-14. [CrossRef]

21. Chen, X.; Lv, Z.; Zhang, C.; Wang, X.; Zhao, Y.; Wang, X.; Zheng, Y. Panax notoginseng saponins regulate VEGF to suppress esophageal squamous cell carcinoma progression via DVL3-mediated Wnt/ $\beta$-catenin signaling. RSC Adv. 2020, 10, 3256-3265. [CrossRef]

22. He, S.; Lyu, F.; Lou, L.; Liu, L.; Li, S.; Jakowitsch, J.; Ma, Y. Anti-tumor activities of Panax quinquefolius saponins and potential biomarkers in prostate cancer. J. Ginseng. Res. 2020, in press. [CrossRef]

23. Cao, X.W.; Wang, F.J.; Liew, O.-W.; Lu, Y.Z.; Zhao, J. Analysis of Triterpenoid Saponins Reveals Insights into Structural Features Associated with Potent Protein Drug Enhancement Effects. Mol. Pharm. 2020, 2, 683-694. [CrossRef] [PubMed]

24. Shanmugam, M.K.; Lee, J.H.; Chai, E.Z.P.; Kanchi, M.M.; Kar, S.; Arfuso, F.; Dharmarajan, A.; Kumar, A.P.; Ramar, P.S.; Looi, C.Y.; et al. Cancer prevention and therapy through the modulation of transcription factors by bioactive natural compounds. Semin. Cancer Biol. 2016, 40-41, 35-47. [CrossRef] [PubMed]

25. Bishayee, A.; Sethi, G. Bioactive natural products in cancer prevention and therapy: Progress and promise. Semin. Cancer Biol. 2016, 1-3. [CrossRef] [PubMed]

26. Deorukhkar, A.; Krishnan, S.; Sethi, G.; Aggarwal, B.B. Back to basics: How natural products can provide the basis for new therapeutics. Expert Opin. Investig. Drugs. 2007, 16, 1753-1773. [CrossRef]

27. Shanmugam, M.K.; Kannaiyan, R.; Sethi, G. Targeting cell signaling and apoptotic pathways by dietary agents: Role in the prevention and treatment of cancer. Nutr. Cancer 2011, 63, 161-173. [CrossRef] 
28. Luan, X.; Guan, Y.Y.; Wang, C.; Zhao, M.; Lu, Q.; Tang, Y.B.; Liu, Y.R.; Yu, D.H.; Wang, X.L.; Qi, H.; et al. Determination of Raddeanin A in rat plasma by liquid chromatography-tandem mass spectrometry: Application to a pharmacokinetic study. J. Chromatogr. B Anal. Technol. Biomed. Life Sci. 2013, 923, 43-47. [CrossRef]

29. Sun, Y.X.; Liu, J.C.; Liu, D.Y. Phytochemicals and bioactivities of Anemone raddeana Regel: A review. Pharmazie. 2011, 66, 813-821.

30. Yamashita, K.; Lu, H.; Lu, J.; Chen, G.; Yokoyama, T.; Sagara, Y.; Manabe, M.; Kodama, H. Effect of three triterpenoids, lupeol, betulin, and betulinic acid on the stimulus-induced superoxide generation and tyrosyl phosphorylation of proteins in human neutrophils. Clin. Chim. Acta. 2002, 325, 91-96. [CrossRef]

31. Qian, S.; Chen, Q.L.; Guan, J.L.; Wu, Y.; Wang, Z.Y. Synthesis and biological evaluation of Raddeanin A, a triterpene saponin isolated from Anemone raddeana. Chem. Pharm. Bull. 2014, 62, 779-785. [CrossRef] [PubMed]

32. Wu, F.E.; Koike, K.; Ohmoto, T.; Chen, W.X. Saponins from Chinese folk medicine, "zhu jie xiang fu," Anemone raddeana Regel. Chem. Pharm. Bull. (Tokyo). 1989, 37, 2445-2447. [CrossRef] [PubMed]

33. Hao, D.C.; Gu, X.; Xiao, P. Anemone medicinal plants: ethnopharmacology, phytochemistry and biology. Acta Pharm. Sin. B 2017, 7, 146-158. [CrossRef] [PubMed]

34. Sun, Y.; Li, M.; Immunopharmacology, J.L.I. Haemolytic activities and adjuvant effect of Anemone raddeana saponins (ARS) on the immune responses to ovalbumin in mice. Int. Immunopharmacol. 2018, 8, 1095-1102. [CrossRef]

35. Gao, Y.; An, J.; Zhu, Q.; Li, F.; Ma, C.; Wang, M.; Tang, Y. Inhibitory effect of raddeanin a in human non-small cell lung cancer $\mathrm{H} 460$ cells. Chin. J. Appl. Environ. Biol. 2010, 16, 637-641.

36. Wang, Q.; Mo, J.; Zhao, C.; Huang, K.; Feng, M.; He, W.; Wang, J.; Chen, S.; Xie, Z.; Ma, J.; et al. Raddeanin A suppresses breast cancer associated osteolysis through inhibiting osteoclasts and breast cancer cells. Cell Death Dis. 2018, 9, 376. [CrossRef]

37. Teng, Y.; Li, J.; Liu, S.; Zou, X.; Fang, L.; Zhou, J.; Wu, J.; Xi, S.; Chen, Y.; Zhang, Y.; et al. Autophagy Protects from Raddeanin A-Induced Apoptosis in SGC-7901 Human Gastric Cancer Cells. Evidence-Based Compl. Alt. Med. 2016, 2016, 1-8. [CrossRef]

38. Li, J.N.; Yu, Y.; Zhang, Y.F.; Li, Z.M.; Cai, G.Z.; Gong, J.Y. Synergy of Raddeanin A and Cisplatin induced 1 Therapeutic Effect2 Enhancement in Human Hepatocellular Carcinoma. Biochem. Biophys. Res. Commun. 2017, 485, 335-341. [CrossRef]

39. Khwairakpam, A.D.; Bordoloi, D.; Thakur, K.K.; Monisha, J.; Arfuso, F.; Sethi, G.; Mishra, S.; Kumar, A.P.; Kunnumakkara, A.B. Possible use of Punica granatum (Pomegranate) in cancer therapy. Pharmacol. Res. 2018, 133, 53-64. [CrossRef]

40. Ranaware, A.M.; Banik, K.; Deshpande, V.; Padmavathi, G.; Roy, N.K.; Sethi, G.; Fan, L.; Kumar, A.P.; Kunnumakkara, A.B. Magnolol: A neolignan from the Magnolia family for the prevention and treatment of cancer. Int. J. Mol. Sci. 2018, 19, 2362. [CrossRef]

41. Kunnumakkara, A.B.; Sailo, B.L.; Banik, K.; Harsha, C.; Prasad, S.; Gupta, S.C.; Bharti, A.C.; Aggarwal, B.B. Chronic diseases, inflammation, and spices: How are they linked? J. Transl. Med. 2018, 16, 14. [CrossRef] [PubMed]

42. Sailo, B.L.; Banik, K.; Padmavathi, G.; Javadi, M.; Bordoloi, D.; Kunnumakkara, A.B. Tocotrienols: The promising analogues of vitamin E for cancer therapeutics. Pharmacol. Res. 2018, 130, 259-272. [CrossRef] [PubMed]

43. Baek, S.-H.; Ko, J.-H.; Lee, J.H.; Kim, C.; Lee, H.; Nam, D.; Lee, J.; Lee, S.G.; Yang, W.M.; Um, J.Y.; et al. Ginkgolic Acid Inhibits Invasion and Migration and TGF- $\beta$-Induced EMT of Lung Cancer Cells Through PI3K/Akt/mTOR Inactivation. J. Cell. Physiol. 2017, 232, 346-354. [CrossRef] [PubMed]

44. Singh, S.S. Targeting the PI3K/Akt signaling pathway in gastric carcinoma: A reality for personalized medicine? World J. Gastroenterol. 2015, 21, 12261. [CrossRef] [PubMed]

45. Li, F.; Shanmugam, M.K.; Chen, L.; Chatterjee, S.; Basha, J.; Kumar, A.P.; Kundu, T.K.; Sethi, G. Garcinol, a polyisoprenylated benzophenone modulates multiple proinfl ammatory signaling cascades leading to the suppression of growth and survival of head and neck carcinoma. Cancer Prev. Res. 2013, 6, 843-854. [CrossRef] 
46. Sethi, G.; Chatterjee, S.; Rajendran, P.; Li, F.; Shanmugam, M.K.; Wong, K.F.; Kumar, A.P.; Senapati, P.; Behera, A.K.; Hui, K.M.; et al. Inhibition of STAT3 dimerization and acetylation by garcinol suppresses the growth of human hepatocellular carcinoma in vitro and in vivo. Mol. Cancer 2014, 13, 66. [CrossRef]

47. Lee, M.; Hirpara, J.L.; Eu, J.Q.; Sethi, G.; Wang, L.; Goh, B.C.; Wong, A.L. Targeting STAT3 and oxidative phosphorylation in oncogene-addicted tumors. Redox Biol. 2019, 25, 101073. [CrossRef]

48. Arora, L.; Kumar, A.P.; Arfuso, F.; Chng, W.J.; Sethi, G. The role of signal transducer and activator of transcription 3 (STAT3) and its targeted inhibition in hematological malignancies. Cancers (Basel) 2018, 10, 327. [CrossRef]

49. Wong, A.L.A.; Hirpara, J.L.; Pervaiz, S.; Eu, J.Q.; Sethi, G.; Goh, B.C. Do STAT3 inhibitors have potential in the future for cancer therapy? Expert Opin. Investig. Drugs. 2017, 26, 883-887. [CrossRef]

50. Rajendran, P.; Li, F.; Shanmugam, M.K.; Vali, S.; Abbasi, T.; Kapoor, S.; Ahn, K.S.; Kumar, A.P.; Sethi, G. Honokiol inhibits signal transducer and activator of transcription-3 signaling, proliferation, and survival of hepatocellular carcinoma cells via the protein tyrosine phosphatase SHP-1. J. Cell. Physiol. 2012, 227, 2184-2195. [CrossRef]

51. Sethi, G.; Ahn, K.S.; Sung, B.; Aggarwal, B.B. Pinitol targets nuclear factor-кB activation pathway leading to inhibition of gene products associated with proliferation, apoptosis, invasion, and angiogenesis. Mol. Cancer Ther. 2008, 7, 1604-1614. [CrossRef] [PubMed]

52. Ahn, K.S.; Sethi, G.; Aggarwal, B.B. Reversal of chemoresistance and enhancement of apoptosis by statins through down-regulation of the NF-кB pathway. Biochem. Pharmacol. 2008, 75, 907-913. [CrossRef] [PubMed]

53. Puar, Y.R.; Shanmugam, M.K.; Fan, L.; Arfuso, F.; Sethi, G.; Tergaonkar, V. Evidence for the involvement of the master transcription factor NF- $\mathrm{B}$ in cancer initiation and progression. Biomedicines 2018, 6, 82. [CrossRef] [PubMed]

54. Loh, C.Y.; Arya, A.; Naema, A.F.; Wong, W.F.; Sethi, G.; Looi, C.Y. Signal transducer and activator of transcription (STATs) proteins in cancer and inflammation: Functions and therapeutic implication. Front. Oncol. 2019, 9, 48. [CrossRef] [PubMed]

55. Hemmings, B.A.; Restuccia, D.F. PI3K-PKB/Akt pathway. Cold Spring Harb. Perspect. Biol. 2012, 4, a011189. [CrossRef]

56. Altomare, D.A.; Testa, J.R. Perturbations of the AKT signaling pathway in human cancer. Oncogene 2005, 24, 7455-7464. [CrossRef]

57. Ong, P.S.; Wang, L.Z.; Dai, X.; Tseng, S.H.; Loo, S.J.; Sethi, G. Judicious toggling of mTOR activity to combat insulin resistance and cancer: Current evidence and perspectives. Front. Pharmacol. 2016, 7, 363. [CrossRef]

58. Manna, S.K.; Aggarwal, R.S.; Sethi, G.; Aggarwal, B.B.; Ramesh, G.T. Morin (3,5,7,2' '4' -pentahydroxyflavone) abolishes nuclear factor- $\mathrm{KB}$ activation induced by various carcinogens and inflammatory stimuli, leading to suppression of nuclear factor-kB - Regulated gene expression and up-regulation of apoptosis. Clin. Cancer Res. 2007, 13, 2290-2297. [CrossRef]

59. Kwang, S.A.; Sethi, G.; Chaturvedi, M.M.; Aggarwal, B.B. Simvastatin, 3-hydroxy-3-methylglutaryl coenzyme A reductase inhibitor, suppresses osteoclastogenesis induced by receptor activator of nuclear factor- $\mathrm{kB}$ ligand through modulation of NF-kB pathway. Int. J. Cancer 2008, 123, 1733-1740.

60. Shin, E.M.; Hay, H.S.; Lee, M.H.; Goh, J.N.; Tan, T.Z.; Sen, Y.P.; Lim, S.W.; Yousef, E.M.; Ong, H.T.; Thike, A.A.; et al. DEAD-box helicase DP103 defines metastatic potential of human breast cancers. J. Clin. Investig. 2014, 124, 3807-3824. [CrossRef]

61. Siveen, K.S.; Ahn, K.S.; Ong, T.H.; Shanmugam, M.K.; Li, F.; Yap, W.N.; Kumar, A.P.; Fong, C.W.; Tergaonkar, V.; Hui, K.M.; et al. $\gamma$-tocotrienol inhibits angiogenesis-dependent growth of human hepatocellular carcinoma through abrogation of AKT/mTOR pathway in an orthotopic mouse model. Oncotarget. 2014, 5, 1897-1911. [CrossRef] [PubMed]

62. Vanhaesebroeck, B.; Leevers, S.J.; Ahmadi, K.; Timms, J.; Katso, R.; Driscoll, P.C.; Woscholski, R.; Parker, P.J.; Waterfield, M.D. Synthesis and Function of 3-Phosphorylated Inositol Lipids. Annu. Rev. Biochem. 2001, 70, 535-602. [CrossRef]

63. Beagle, B.; Fruman, D.A. A lipid kinase cousin cooperates to promote cancer. Cancer Cell 2011, 19, 693-695. [CrossRef]

64. Soler, A.; Serra, H.; Pearce, W.; Angulo, A.; Guillermet-Guibert, J.; Friedman, L.S.; Viñals, F.; Gerhardt, H.; Casanovas, O.; Graupera, M.; et al. Inhibition of the p110 $\alpha$ isoform of PI 3-kinase stimulates nonfunctional tumor angiogenesis. J. Exp. Med. 2013, 210, 1937-1945. [CrossRef] [PubMed] 
65. Hirsch, E.; Ciraolo, E.; Franco, I.; Ghigo, A.; Martini, M. PI3K in cancer-stroma interactions: Bad in seed and ugly in soil. Oncogene 2014, 33, 3083-3090. [CrossRef] [PubMed]

66. Fu, L.L.; Xie, T.; Zhang, S.Y.; Liu, B. Eukaryotic elongation factor-2 kinase (eEF2K): A potential therapeutic target in cancer. Apoptosis 2014, 19, 1527-1531. [CrossRef] [PubMed]

67. Guan, Y.; Jiang, S.; Yu, P.; Wen, M.; Zhang, Y.; Xiao, S.; Xu, X.; Cheng, Y. Suppression of eEF-2K-mediated autophagy enhances the cytotoxicity of raddeanin A against human breast cancer cells in vitro. Nat. Publ. Gr. 2017, 39, 642-648. [CrossRef]

68. Wang, X.; da Mota, S.R.; Liu, R.; Moore, C.E.; Xie, J.; Lanucara, F.; Agarwala, U.; Pyr Dit Ruys, S.; Vertommen, D.; Rider, M.H.; et al. Eukaryotic elongation factor 2 kinase activity is controlled by multiple inputs from oncogenic signaling. Mol. Cell. Biol. 2014, 34, 4088-4103. [CrossRef]

69. Guo, S.S.; Wang, Y.; Fan, Q.X. Raddeanin A promotes apoptosis and ameliorates 5-fluorouracil resistance in cholangiocarcinoma cells. World J. Gastroenterol. 2019, 25, 3380-3391. [CrossRef]

70. Boyle, W.J.; Simonet, W.S.; Lacey, D.L. Osteoclast differentiation and activation. Nature 2003, 423, 337-342. [CrossRef]

71. Feng, X. RANKing intracellular signaling in osteoclasts. IUBMB Life 2005, 57, 389-395. [CrossRef] [PubMed]

72. Wada, T.; Nakashima, T.; Hiroshi, N.; Penninger, J.M. RANKL-RANK signaling in osteoclastogenesis and bone disease. Trends Mol. Med. 2006, 12, 17-25. [CrossRef] [PubMed]

73. Molenaar, M.; Van De Wetering, M.; Oosterwegel, M.; Peterson-Maduro, J.; Godsave, S.; Korinek, V.; Roose, J.; Destrée, O.; Clevers, H. XTcf-3 transcription factor mediates $\beta$-catenin-induced axis formation in xenopus embryos. Cell 1996, 86, 391-399. [CrossRef]

74. MacDonald, B.T.; Tamai, K.; He, X. Wnt/ $\beta$-Catenin Signaling: Components, Mechanisms, and Diseases. Dev. Cell 2009, 17, 9-26. [CrossRef] [PubMed]

75. El Hasasna, H.; Athamneh, K.; Al Samri, H.; Karuvantevida, N.; Al Dhaheri, Y.; Hisaindee, S.; Ramadan, G.; Al Tamimi, N.; AbuQamar, S.; Eid, A.; et al. Rhus coriaria induces senescence and autophagic cell death in breast cancer cells through a mechanism involving p38 and ERK1/2 activation. Sci. Rep. 2015, 5, 1-18. [CrossRef] [PubMed]

76. Paiva, C.; Godbersen, J.C.; Soderquist, R.S.; Rowland, T.; Kilmarx, S.; Spurgeon, S.E.; Brown, J.R.; Srinivasa, S.P.; Danilov, A.V. Cyclin-Dependent Kinase Inhibitor P1446A Induces Apoptosis in a JNK/p38 MAPK-Dependent Manner in Chronic Lymphocytic Leukemia B-Cells. PLoS ONE 2015, 10, e0143685. [CrossRef]

77. Chun, J.; Joo, E.J.; Kang, M.; Kim, Y.S. Platycodin D induces anoikis and caspase-mediated apoptosis via p38 MAPK in AGS human gastric cancer cells. J. Cell. Biochem. 2013, 114, 456-470. [CrossRef]

78. Wang, Z.; Wang, C.; Zuo, D.; Zhang, T.; Yin, F.; Zhou, Z. Attenuation of STAT3 Phosphorylation Promotes Apoptosis and Chemosensitivity in Human Osteosarcoma Induced by Raddeanin A. Int. J. Biol. Sci. 2019, 15, 668-679. [CrossRef]

79. Guan, Y.; Liu, H.; Luan, X.; Xu, J.; Lu, Q.; Liu, Y.; Gao, Y.; Zhao, M.; Chen, H.; Fang, C. Raddeanin A, a triterpenoid saponin isolated from Anemone raddeana, suppresses the angiogenesis and growth of human colorectal tumor by inhibiting VEGFR2 signaling. Phytomedicine 2014, 22, 103-110. [CrossRef]

80. Yu, K.; Chen, F. Absorption, disposition, and pharmacokinetics of saponins from Chinese medicinal herbs: what do we know and what do we need to know more? Curr. Drug. Metab. 2012, 13, 577-598. [CrossRef]

81. Wang, W.; Wang, G.; Xie, H.; Sun, J. Determination of ginsenoside Rd in dog plasma by liquid chromatography-mass spectrometry after solid-phase extraction and its application in dog pharmacokinetics. J. Chromatogr. B. Analyt. Technol. Biomed. Life Sci. 2007, 852, 8-14. [CrossRef] [PubMed]

82. Gu, G.; Qi, H.; Jiang, T.; Ma, B.O.; Fang, Z.; Xu, H.; Zhang, Q.I. Investigation of the cytotoxicity, apoptosis and pharmacokinetics of Raddeanin A. Oncol. Lett. 2017, 1365-1369.

83. Liu, Y.; Ma, B.; Zhang, Q.; Ying, H.; Li, J.; Xu, Q.; Wu, D.; Wang, Y. Development and validation of a sensitive liquid chromatography / tandem mass spectrometry method for the determination of raddeanin A in rat plasma and its application to a pharmacokinetic study. J Chromatogr B. Analyt. Technol. Biomed. Life Sci. 2013, 912, 16-23. [CrossRef] [PubMed]

84. Chen, L.; Yuan, Y.; Kar, S.; Kanchi, M.M.; Arora, S.; Kim, J.E.; Koh, P.F.; Yousef, E.; Samy, R.P.; Shanmugam, M.K.; et al. PPAR $\gamma$ ligand-induced annexin A1 expression determines chemotherapy response via deubiquitination of death domain kinase RIP in triple-negative breast cancers. Mol. Cancer Ther. 2017, 16, 2528-2542. [CrossRef] [PubMed] 
85. Niu, Y.; Zhou, G.; Wang, Y.; Qin, J.; Ping, J.; Zhang, Q.; Han, B.W.; Liu, Y.X.; Yang, C.; Zhai, Y.; et al. Association of MCP-1 promoter polymorphism with susceptibility to nasopharyngeal carcinoma. J. Cell. Biochem. 2019, 120, 6661-6670. [CrossRef]

86. Rani, N.Z.A.; Husain, K.; Kumolosasi, E. Moringa genus: A review of phytochemistry and pharmacology. Front. Pharmacol. 2018, 9, 9.

87. Wang, C.; Kar, S.; Lai, X.; Cai, W.; Arfuso, F.; Sethi, G.; Lobie, P.E.; Goh, B.C.; Lim, L.H.K.; Hartman, M.; et al. Triple negative breast cancer in Asia: An insider's view. Cancer. Treat. Rev. 2018, 62, 29-38. [CrossRef]

88. Liu, L.; Ahn, K.S.; Shanmugam, M.K.; Wang, H.; Shen, H.; Arfuso, F.; Chinnathambi, A.; Alharbi, S.A.; Chang, Y.; Sethi, G.; et al. Oleuropein induces apoptosis via abrogating NF- $\mathrm{kB}$ activation cascade in estrogen receptor-negative breast cancer cells. J. Cell. Biochem. 2019, 120, 4504-4513. [CrossRef]

89. Clines, G.A.; Guise, T.A. Hypercalcaemia of malignancy and basic research on mechanisms responsible for osteolytic and osteoblastic metastasis to bone. Endocr. Relat. Cancer. 2005, 12, 549-583. [CrossRef]

90. Chen, Y.C.; Sosnoski, D.M.; Mastro, A.M. Breast cancer metastasis to the bone: Mechanisms of bone loss. Breast. Cancer. Res. 2010, 12, 215. [CrossRef]

91. Farooq, M.; Egan, J.B.; McDonald, B.; Markus, H.; Contente-Cuomo, T.; Fernandez-Zapico, M.; Vasmatzis, G.; Braggio, E.; Borad, M.J.; Murtaza, M. Detection of copy number aberrations in cholangiocarcinoma using shallow whole genome sequencing of plasma DNA. J. Clin. Oncol. 2018, 36, 293. [CrossRef]

92. Kitdumrongthum, S.; Metheetrairut, C.; Charoensawan, V.; Ounjai, P.; Janpipatkul, K.; Panvongsa, W.; Weerachayaphorn, J.; Piyachaturawat, P.; Chairoungdua, A. Dysregulated microRNA expression profiles in cholangiocarcinoma cell-derived exosomes. Life Sci. 2018, 210, 65-75. [CrossRef] [PubMed]

93. Qin, W.; Kang, P.; Xu, Y.; Leng, K.; Li, Z.; Huang, L.; Gao, J.; Cui, Y.; Zhong, X. Long non-coding RNA HOTAIR promotes tumorigenesis and forecasts a poor prognosis in cholangiocarcinoma. Sci. Rep. 2018, 8 , 12176. [CrossRef] [PubMed]

94. González-Vallinas, M.; Molina, S.; Vicente, G.; De La Cueva, A.; Vargas, T.; Santoyo, S.; García-Risco, M.R.; Fornari, T.; Reglero, G.; De Molina, A.R. Antitumor effect of 5-fluorouracil is enhanced by rosemary extract in both drug sensitive and resistant colon cancer cells. Pharmacol. Res. 2013, 72, 61-68. [CrossRef] [PubMed]

95. Otto, T.; Sicinski, P. Cell cycle proteins as promising targets in cancer therapy. Nat. Rev. Cancer 2017, 17, 93-115. [CrossRef]

96. Hirai, H.; Iwasawa, Y.; Okada, M.; Arai, T.; Nishibata, T.; Kobayashi, M.; Kimura, T.; Kaneko, N.; Ohtani, J.; Yamanaka, K.; et al. Small-molecule inhibition of Wee1 kinase by MK-1775 selectively sensitizes p53-deficient tumor cells to DNA-damaging agents. Mol. Cancer Ther. 2009, 8, 2992-3000. [CrossRef]

97. Bartek, J.; Lukas, J. Pathways governing G1/S transition and their response to DNA damage. FEBS Lett. 2001, 490, 117-122. [CrossRef]

98. Coco Martin, J.M.; Balkenende, A.; Verschoor, T.; Lallemand, F.; Michalides, R. Cyclin D1 overexpression enhances radiation-induced apoptosis and radiosensitivity in a breast tumor cell line. Cancer Res. 1999, 59, 1134-1140.

99. Aggarwal, B.; Prasad, S.; Sung, B.; Krishnan, S.; Guha, S. Prevention and treatment of colorectal cancer by natural agents from mother nature. Curr. Colorectal. Cancer. Rep. 2013, 9, 37-56. [CrossRef]

100. Deorukhkar, A.; Ahuja, N.; Mercado, A.L.; Diagaradjane, P.; Raju, U.; Patel, N.; Mohindra, P.; Diep, N.; Guha, S.; Krishnan, S. Zerumbone increases oxidative stress in a thiol-dependent ROS-independent manner to increase DNA damage and sensitize colorectal cancer cells to radiation. Cancer. Med. 2015, 4, 278-292. [CrossRef]

101. Hanahan, D.; Weinberg, R.A. Hallmarks of cancer: The next generation. Cell 2011, 144, 646-674. [CrossRef]

102. Teng, Y.; Jiang, X. Raddeanin A Induces Apoptosis and Cycle Arrest in Human HCT116 Cells through PI3K/ AKT Pathway Regulation In Vitro and In Vivo. Evidence-Based Complement. Altern. Med. 2019, 2019, 1-11.

103. Wang, Y.; Bao, X.; Zhao, A.; Zhang, J.; Zhang, M. Raddeanin A inhibits growth and induces apoptosis in human colorectal cancer through downregulating the Wnt/ $\beta$-catenin and NF-kB signaling pathway. Life Sci. 2018. [CrossRef] [PubMed]

104. Gibbons, R.J.; Smith, S.; Antman, E. American College of Cardiology/American Heart Association clinical practice guidelines: Part I. Where do they come from? Circulation. 2003, 107, 2979-2986. [CrossRef] [PubMed]

105. Faris, P.; Shekha, M.; Montagna, D.; Guerra, G.; Moccia, F. Endolysosomal Ca ${ }^{2+}$ signalling and cancer hallmarks: Two-pore channels on the move, TRPML1 lags behind! Cancers (Basel) 2019, 11, 27. [CrossRef] [PubMed] 
106. Gilbert, M.R.; Dignam, J.J.; Armstrong, T.S.; Wefel, J.S.; Blumenthal, D.T.; Vogelbaum, M.A.; Colman, H.; Chakravarti, A.; Pugh, S.; Won, M.; et al. A randomized trial of bevacizumab for newly diagnosed glioblastoma. N. Engl. J. Med. 2014, 370, 699-708. [CrossRef]

107. Peng, F.; Wang, X.; Shu, M.; Yang, M.; Wang, L.; Ouyang, Z.; Shen, C.; Hou, X.; Zhao, B.; Wang, X.; et al. Raddeanin a Suppresses Glioblastoma Growth by Inducing ROS Generation and Raddeanin a Suppresses Glioblastoma Growth by Inducing ROS Generation and Subsequent JNK Activation to Promote Cell Apoptosis. N. Engl. J. Med. 2018, 8, 1108-1121.

108. Wang, C.; Zhang, J.; Cai, M.; Zhu, Z.; Gu, W.; Yu, Y.; Zhang, X. DBGC: A database of human gastric cancer. PLoS ONE 2015, 10, e0142591. [CrossRef]

109. Ji, Y.B.; Qu, Z.Y.; Zou, X. Juglone-induced apoptosis in human gastric cancer SGC-7901 cells via the mitochondrial pathway. Exp. Toxicol. Pathol. 2011, 63, 69-78.

110. Manu, K.A.; Shanmugam, M.K.; Rajendran, P.; Li, F.; Ramachandran, L.; Hay, H.S.; Kannaiyan, R.; Swamy, S.N.; Vali, S.; Kapoor, S.; et al. Plumbagin inhibits invasion and migration of breast and gastric cancer cells by downregulating the expression of chemokine receptor CXCR4. Mol. Cancer 2011, 10, 107. [CrossRef]

111. Manu, K.A.; Shanmugam, M.K.; Ramachandran, L.; Li, F.; Fong, C.W.; Kumar, A.P.; Tan, P.; Sethi, G. First evidence that $\gamma$-tocotrienol inhibits the growth of human gastric cancer and chemosensitizes it to capecitabine in a xenograft mouse model through the modulation of NF-kB pathway. Clin. Cancer Res. 2012, 18, 2220-2229. [CrossRef]

112. Ramachandran, L.; Manu, K.A.; Shanmugam, M.K.; Li, F.; Siveen, K.S.; Vali, S.; Kapoor, S.; Abbasi, T.; Surana, R.; Smoot, D.T.; et al. Isorhamnetin inhibits proliferation and invasion and induces apoptosis through the modulation of peroxisome proliferator-activated receptor $\gamma$ activation pathway in gastric cancer. J. Biol. Chem. 2012, 287, 38028-38040. [CrossRef] [PubMed]

113. Manu, K.A.; Shanmugam, M.K.; Li, F.; Chen, L.; Siveen, K.S.; Ahn, K.S.; Kumar, A.P.; Sethi, G. Simvastatin sensitizes human gastric cancer xenograft in nude mice to capecitabine by suppressing nuclear factor-kappa B-regulated gene products. J. Mol. Med. 2014, 92, 267-276. [CrossRef] [PubMed]

114. Manu, K.A.; Shanmugam, M.K.; Ramachandran, L.; Li, F.; Siveen, K.S.; Chinnathambi, A.; Zayed, M.E.; Alharbi, S.A.; Arfuso, F.; Kumar, A.P.; et al. Isorhamnetin augments the anti-tumor effect of capeciatbine through the negative regulation of NF-kB signaling cascade in gastric cancer. Cancer Lett. 2015, 363, 28-36. [CrossRef] [PubMed]

115. Xue, G.; Zou, X.; Zhou, J.; Sun, W.; Wu, J.; Xu, J.L.; Wang, R.P. Raddeanin A induces human gastric cancer cells apoptosis and inhibits their invasion in vitro. Biochem. Biophys. Res. Commun. 2013, 439, 196-202. [CrossRef] [PubMed]

116. Shim, S.J.; Seong, J.; Lee, I.J.; Han, K.H.; Chon, C.Y.; Ahn, S.H. Radiation-induced hepatic toxicity after radiotherapy combined with chemotherapy for hepatocellular carcinoma. Hepatol. Res. 2007, 37, 906-913. [CrossRef] [PubMed]

117. Xu, Y.; Wang, N.; Ding, Y.; Wang, C.; Yu, Y.; Liu, S.; Wang, X.; Li, Z. Ammonium chloride enhances cisplatin cytotoxicity through DNA double-strand breaks in human cervical cancer cells. Oncol. Rep. 2013, 30, 1195-1200. [CrossRef]

118. Xu, Y.; Li, D.; Zeng, L.; Wang, C.; Zhang, L.; Wang, Y.; Yu, Y.; Liu, S.; Li, Z. Proteasome inhibitor lactacystin enhances cisplatin cytotoxicity by increasing endoplasmic reticulum stress.associated apoptosis in HeLa cells. Mol. Med. Rep. 2015, 11, 189-195. [CrossRef]

119. Wang, G.; Wang, X.; Xu, X. Triptolide potentiates lung cancer cells to cisplatin-induced apoptosis by selectively inhibiting the NER activity. Biomark. Res. 2015, 3, 17. [CrossRef]

120. Liu, R.R.; Lv, Y.S.; Tang, Y.X.; Wang, Y.F.; Chen, X.L.; Zheng, X.X.; Xie, S.Z.; Cai, Y.; Yu, J.; Zhang, X.N. Eukaryotic translation initiation factor $5 \mathrm{~A} 2$ regulates the migration and invasion of hepatocellular carcinoma cells via pathways involving reactive oxygen species. Oncotarget. 2016, 7, 24348-24360. [CrossRef]

121. Pinto-Leite, R.; Arantes-Rodrigues, R.; Ferreira, R.; Palmeira, C.; Colaço, A.; da Silva, V.M.; Oliveira, P.; Santos, L.L. Temsirolimus improves cytotoxic efficacy of cisplatin and gemcitabine against urinary bladder cancer cell lines. Urol. Oncol. Semin. Orig. Investig. 2014, 32, 4111-4122. [CrossRef]

122. Chen, Y.; Ma, Z.; Shen, X.; Li, L.; Zhong, J.; Min, L.S.; Xu, L.; Li, H.; Zhang, J.; Dai, L. Serum Lipidomics Profiling to Identify Biomarkers for Non-Small Cell Lung Cancer. Biomed Res. Int. 2018, 2018, 1-16. [CrossRef] 
123. Ma, B.; Zhu, J.; Zhao, A.; Zhang, J.; Wang, Y.; Zhang, L.; Zhang, Q.; Zhu, J.; Zhao, A.; Zhang, J.; et al. Raddeanin A, a natural triterpenoid saponin compound, exerts anticancer effect on human osteosarcoma via the ROS/JNK and NF-кB signal pathway. Toxicol. Appl. Pharmacol. 2018, 353, 87-101. [CrossRef] [PubMed]

124. Wang, Z.; Shen, J.; Sun, W.; Zhang, T.; Zuo, D.; Wang, H.; Wang, G.; Xu, J.; Yin, F.; Mao, M.; et al. Antitumor activity of Raddeanin $\mathrm{A}$ is mediated by Jun amino-terminal kinase activation and signal transducer and activator of transcription 3 inhibition in human osteosarcoma. Cancer Sci. 2019, 110, 1746-1759. [CrossRef] [PubMed]

125. Lin, C.J.; Lo, U.G.; Hieh, J.T. The regulatory pathways leading to stem-like cells underlie prostate cancer progression. Asian J. Androl. 2019, 21, 233-240. [PubMed]

126. Zainfeld, D.; Goldkorn, A. Liquid biopsy in prostate cancer: Circulating tumor cells and beyond. Int. Cancer Treatment and Res. 2018, 175, 87-104.

127. Zhang, G.; Liu, X.; Li, J.; Ledet, E.; Alvarez, X.; Qi, Y.; Fu, X.; Sartor, O.; Dong, Y.; Zhang, H. Androgen receptor splice variants circumvent AR blockade by microtubule-targeting agents. Oncotarget. 2015, 6, 23358-23371. [CrossRef]

128. Cai, C.; He, H.H.; Chen, S.; Coleman, I.; Wang, H.; Fang, Z.; Chen, S.; Nelson, P.S.; Liu, X.S.; Brown, M.; et al. Androgen Receptor Gene Expression in Prostate Cancer Is Directly Suppressed by the Androgen Receptor Through Recruitment of Lysine-Specific Demethylase 1. Cancer Cell 2011, 20, 457-471. [CrossRef]

129. Cao, B.; Liu, X.; Li, J.; Liu, S.; Qi, Y.; Xiong, Z.; Zhang, A.; Wiese, T.; Fu, X.; Gu, J.; et al. 20(S)-protopanaxadiol-Aglycone downregulation of the full-length and splice variants of androgen receptor. Int. J. Cancer 2013, 132, 1277-1287. [CrossRef]

130. Wang, B.; Lo, U.G.; Wu, K.; Kapur, P.; Liu, X.; Huang, J.; Chen, W.; Hernandez, E.; Santoyo, J.; Ma, S.H.; et al. Developing new targeting strategy for androgen receptor variants in castration resistant prostate cancer. Int. J. Cancer 2017, 141, 2121-2130. [CrossRef]

131. Ponnusamy, S.; Coss, C.C.; Thiyagarajan, T.; Watts, K.; Hwang, D.J.; He, Y.; Selth, L.A.; McEwan, I.J.; Duke, C.B.; Pagadala, J.; et al. Novel selective agents for the degradation of androgen receptor variants to treat castration-resistant prostate cancer. Cancer Res. 2017, 77, 6282-6298. [CrossRef]

132. Yuan, R.; Hou, Y.; Sun, W.; Yu, J.; Liu, X.; Niu, Y.; Lu, J.J.; Chen, X. Natural products to prevent drug resistance in cancer chemotherapy: a review. Ann. N. Y. Acad. Sci. 2017, 1401, 19-27. [CrossRef] [PubMed]

133. Galletti, G.; Leach, B.I.; Lam, L.; Tagawa, S.T. Mechanisms of resistance to systemic therapy in metastatic castration-resistant prostate cancer. Cancer Treat. Rev. 2017, 57, 16-27. [CrossRef] [PubMed]

134. Rajendran, P.; Li, F.; Manu, K.A.; Shanmugam, M.K.; Loo, S.Y.; Kumar, A.P.; Sethi, G. $\gamma$-Tocotrienol is a novel inhibitor of constitutive and inducible STAT3 signalling pathway in human hepatocellular carcinoma: Potential role as an antiproliferative, pro-apoptotic and chemosensitizing agent. Br. J. Pharmacol. 2011, 163, 283-298. [CrossRef]

135. Noordhuis, P.; Holwerda, U.; Van der Wilt, C.L.; Van Groeningen, C.J.; Smid, K.; Meijer, S.; Pinedo, H.M.; Peters, G.J. 5-Fluorouracil incorporation into RNA and DNA in relation to thymidylate synthase inhibition of human colorectal cancers. Ann. Oncol. 2004, 15, 1025-1032. [CrossRef] [PubMed]

136. Xia, H.; Hu, C.; Bai, S.; Lyu, J.; Zhang, B.Y.; Yu, X.; Zhan, Y.; Zhao, L.; Dong, Y. Raddeanin A down regulates androgen receptor and its splice variants in prostate cancer. J. Chromatogr. B Anal. Technol. Biomed. Life Sci. 2019, 23, 3656-3664. [CrossRef] [PubMed]

137. Egan, A.; Dong, Y.; Zhang, H.; Qi, Y.; Balk, S.P.; Sartor, O. Castration-resistant prostate cancer: Adaptive responses in the androgen axis. Cancer Treat. Rev. 2014, 40, 426-433. [CrossRef]

138. Peng, Z.; Zhang, C.; Zhou, W.; Wu, C.; Zhang, Y. The STAT3/NFIL3 signaling axis-mediated chemotherapy resistance is reversed by Raddeanin A via inducing apoptosis in choriocarcinoma cells. J. Cell. Physiol. 2018, 233, 5370-5382. [CrossRef]

(C) 2020 by the authors. Licensee MDPI, Basel, Switzerland. This article is an open access article distributed under the terms and conditions of the Creative Commons Attribution (CC BY) license (http://creativecommons.org/licenses/by/4.0/). 